№ 1 (4), 2021

УДК 621.315.21

Ю. О. Варецький

Національний університет “Львівська політехніка”, кафедра електроенергетики та систем управління, j.varetsky@gmail.com

\title{
МЕТОД ОЦІКИ ВТРАТ ПОТУЖНОСТІ У КАБЕЛЯХ НИЗЬКОЇ НАПРУГИ ПРОМИСЛОВИХ ЕЛЕКТРИЧНИХ МЕРЕЖ
}

http://doi.org/10.23939/sepes2021.01.017

(C) Вареиький Ю. О., 2021

Гармоніки струму в кабельних лініях промислових електричних мереж супроводжуються несприятливими явищами, які спричиняють додаткові втрати активної потужності у жилах кабелю. Це призводить до підвищення температури ізоляції кабелю та зменшення терміну їі служби. Часто у цих електричних мережах можна спостерігати пошкодження кабельних ліній, спричинені невдалим урахуванням впливу гармонік. Тому коректне врахування втрат активної потужності в кабелях зі спотвореними струмами дає змогу здійснювати правильний вибір їх перерізів і уникати можливих проблем в експлуатації систем електропостачання. Висвітлено загальну картину проблеми і на прикладі кабельної лінії низької напруги, що живить нелінійне змінне навантаження, показано використання методу оцінювання додаткових втрат потужності, спричинених гармоніками струму.

Ключові слова: кабель низької напруги; втрати активної потужності; промислова електрична мережа; гармоніки струму; нелінійне навантаження.

\section{Проблема}

Для підвищення ефективності перетворення енергії у сучасних системах електроспоживання широко використовують пристрої силової електроніки, які спричиняють значне спотворення струмів у промислових і комунальних розподільних мережах. Внаслідок протікання по лініях i трансформаторах мереж ці струми спричинюють гармонічні спотворення напруги. У силових кабелях гармоніки струму та напруги можуть спричинити істотні додаткові втрати активної потужності в провідниках та ізоляційних матеріалах i, якщо знехтувати ними під час вибору типу i перерізу жил кабелю, то це призведе до зменшення терміну його служби.

Найпоширенішою ізоляцією для кабельних ліній низької та середньої напруги є ізоляція із XLPE. Основним матеріалом ізоляції XLPE є спеціальний тип поліетилену, який додатково зшитий різними молекулами, щоб він міг працювати за високих температур, не пошкоджуючись під час значного навантаження жил кабелю. Робоча температура кабелів із XLPE ізоляцією сягає $90{ }^{\circ} \mathrm{C} . \mathrm{У}$ разі протікання синусоїдного номінального струму термін експлуатації XLPE ізоляції сягає близько 30 років. Наявність вищих гармонік у струмах кабельних ліній спричиняє додаткові втрати потужності внаслідок збільшення діючого значення струму та посилення таких несприятливих явищ, як поверхневий ефект, ефект зближення жил та вплив металевої оболонки кабелю. Це призводить до підвищення температури ізоляції та зменшення терміну експлуатації кабельних ліній.

\section{Актуальність дослідження}

Наведені в [1] результати дослідження, виконаного для кабелю з ізоляцією XLPE $з$ номіналь-

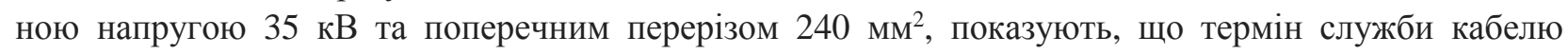


значно зменшується зі збільшенням коефіцієнта спотворення струму $K_{н с l}$. Навіть невелике спотворення струму призводить до зменшення тривалості експлуатації кабелю майже на десять років. Крім того, термін служби кабелю в діапазоні змін $K_{н с I}$ від 10 до $20 \%$ зменшується порівняно повільно, а від $20 \%$ - швидко. Зменшення часу експлуатації кабелю пояснюють істотним підвищенням температури ізоляції відносно допустимого значення, що спричиняє втрату його електричних та механічних властивостей.

Пошкодження кабельних ліній спричиняє великі незручності для споживачів та величезні фінансові втрати для підприємств. Тому важливо правильно визначати додаткові втрати потужності у кабелях під час протікання спотворених струмів, щоб уникнути їх перегрівання.

Відомо, що у трифазних чотирипровідних системах струми гармонік, кратних трьом (нульова послідовність), підсумовуються в нейтральному провіднику. Це явище дуже шкідливе. Якщо, наприклад, струм третьої гармоніки становить $70 \%$ від фазового струму, то в нейтральному провіднику його значення сягатиме $210 \%$. Цей простий приклад дуже добре ілюструє гостроту проблеми.

3 урахуванням цієї особливості та 3 огляду на той факт, що на термін служби кабелів дуже істотно впливає їх робоча температура, яка не повинна бути перевищена, стає зрозумілим, чому проблема перевантаження нульового провідника настільки серйозна й актуальна.

Дослідження, проведені свого часу в деяких комерційних будівлях, показали, що значення струмів, котрі протікають в нейтральних жилах кабелів, містяться в діапазоні від $150 \%$ до $210 \%$ від фазних струмів. Тому переріз цієї жили у мережах з нелінійними навантаженнями не повинен бути меншим від перерізу фазної жили кабелю.

Стандарт МЕК 60364-5-52: 2001 рекомендує поправкові коефіцієнти навантаження, котрі грунтуються на експериментальних дослідженнях і теоретичних розрахунках для типових робочих умов установок низької напруги. Значення коефіцієнта зменшення навантаження для кабелів зі струмами гармонік нульової послідовності подано в табл. 1.

Таблиия 1

Коефіціснт навантаження для кабелів зі струмами гармонік нульової послідовності

\begin{tabular}{|c|c|c|}
\hline $\begin{array}{c}\text { Третя гармоніка фазного струму, } \\
\%\end{array}$ & $\begin{array}{c}\text { Значення фазного струму } \\
\text { відносно номінального }\end{array}$ & $\begin{array}{c}\text { 3начення струму нейтрального } \\
\text { проводу відносно фазного }\end{array}$ \\
\hline $0-15$ & 1,00 & - \\
\hline $15-33$ & 0,86 & 0,86 \\
\hline $33-45$ & - & 1,00 \\
\hline$>45$ & - & - \\
\hline
\end{tabular}

Згідно 3 табл. 1, для струму третьої гармоніки до 15 \% норма не передбачає збільшення поперечного перерізу нейтрального провідника. Тоді струм нейтрального провідника може сягати $45 \%$ фазного струму, а кількість виділеного тепла збільшиться приблизно на $6 \%$ порівняно 3 номінальними навантаженням кабелю, а це допустимо.

Коли гармоніки нульової послідовності будуть у межах 15-33 \%, можна очікувати значення струму в нейтральному проводі на рівні фазного. У цьому випадку необхідно зменшити корисне навантаження кабелю.

Якщо ж струми гармонік, кратних трьом, перевищують $33 \%$ від фазного струму, то навантаження кабелю визначають за значенням струму нейтрального провідника. У такому разі струмове навантаження кабелю повинно бути зменшене до 0,86 від його номінального значення. Якщо ж діюче значення гармонік нульової послідовності перевищує $45 \%$, то переріз жил кабелю визначається виключно струмом нейтрального проводу. У цьому випадку не застосовують коефіцієнт зменшення фазного навантаження жил і поперечний переріз фазних провідників повинен бути перерахований відповідно до струмового навантаження нульового проводу.

Відповідно до чинних вимог, поперечний переріз нейтрального проводу повинен, принаймні, дорівнювати перерізу фазного проводу. Іноді для кожної фазної лінії застосовують окремий нейтральний провід. 


\section{Формулювання мети та завдань статті}

Часто навантаження в низьковольтних електричних мережах є нестаціонарним. Тому значення струмів і їх спотворення в окремих фазах змінюються в часі, спричинюючи змінну в часі несиметрію. Це призводить до появи в нейтральному проводі системи струмів гармонік, не тільки кратних трьом, а й усього спектра гармонік, наявних у фазних струмах. У поданій роботі запропоновано практичний метод оцінки допустимого навантаження кабелю низької напруги в мережі 3 нестаціонарним навантаженням.

\section{Аналіз останніх досліджень і публікацій}

Процедури вибору кабеля для несинусоїдних режимів електричної мережі наведені в літеpaтурі [1-7]. В роботі [1] проаналізовано проблему додаткового нагрівання кабелів в системах електропостачання нелінійних навантажень. В дослідженнях, викладених у статті [2], підсумовано вплив гармонік струму на нагрівання і зниження терміну експлуатації кабелів XLPE в розподільних мережах. В роботах [3-5] подано аналіз і приклади розрахунку додаткових втрат у кабелях та зниження їх навантажувальної здатності через протікання струмів гармонік на основі стандарту IEC Standard 60287-1-1. Подібні підходи до розрахунку втрат у кабелях використано у роботах [6, 5]. Аналіз цих публікацій показує, що пропоновані методи розрахунку грунтуються на міркуваннях загальної оцінки несинусоїдних симетричних режимів і не беруть до уваги особливості, які накладаються специфічними умовами роботи змінних несиметричних навантажень.

\section{Характер втрат у кабелях з нелінійним навантаженням}

Втрати активної потужності у жилах силових кабелів спричинені протіканням струму через провідник. Діюче значення струму нелінійного навантаження містить вищі гармоніки, а активний опір провідника залежить від частоти. Ця залежність опору від частоти струму - одна 3 причин додаткових втрат потужності в кабельних лініях.

На активний опір провідника змінному струму впливає поверхневий ефект, який полягає в тому, що струм у провіднику не протікає рівномірно через увесь поперечний переріз, а його густина зростає із наближенням до поверхні. Що вища частота, то ближче до поверхні провідника витісняється струм (глибина проникнення струму зменшується). Поверхневий ефект зумовлений переважно вихровими струмами від електрорушійної сили, індукованої електромагнітним полем від основного струму в жилі кабелю. Вихрові струми призводять до зменшення основного струму в середині провідника і до збільшення його ближче до поверхні.

Іншим електромагнітним явищем, що впливає на опір провідника, $\epsilon$ ефект зближення. Він виникає під час зближення двох чи більше провідників зі струмом. Якщо струми протікають у одному напрямі, найвища густина струму виникає в найвіддаленіших частинах провідників. У разі протилежних напрямів струму найвищою густина струму буде у найближчих частинах цих провідників. Ефект зближення, подібно до поверхневого ефекту, також зумовлений вихровими струмами. Основний струм у одному з провідників генерує змінне магнітне поле, яке індукує електрорушійну силу в іншому провіднику, яка, своєю чергою, створює вихрові струми, що зменшують густину основного струму в одній частині провідника і збільшують у протилежній. Як правило, кабелі, які застосовують у силових низьковольтних мережах, чотирижильні. Це призводить до того, що у різних жилах виникають магнітні поля різної інтенсивності, які залежать від розташування окремих жил у конструкції кабелю. Дослідження ефекту зближення, здійснені для чотирижильних кабелів, показали [9], що збільшення опору жили за рахунок цього ефекту $є$ однаковим та інтенсивнішим у двох фазних жилах, які прилягають до жили нульового проводу, $\mathrm{i}$ дещо менш інтенсивним для жили третьої фази.

Наступним явищем, яке також впливає на втрати потужності у кабельних лініях, $є$ вплив зовнішньої броньованої захисної оболонки. Він полягає у тому, що основний струм у провіднику індукує електрорушійну силу в зовнішній броньованій оболонці кабелю, створюючи у ній вихрові струми, що призводить до додаткових втрат і підвищення температури кабелю. Це явище теж 


\section{Ю. О. Варецький}

обмежує максимальне корисне навантаження кабельної лінії. Для кабелів з ізоляцією із XLPE цей ефект не $\epsilon$ актуальним, оскільки у їхніх конструкціях вказана оболонка відсутня.

Враховуючи вплив перелічених електромагнітних явищ у кабелях зі спотвореними струмами, загальне збільшення опору жили кабелю можна виразити формулою [2, 4-8]:

$$
R_{(h)}=\left[1+y_{S(h)}+y_{p(h)}+y_{a(h)}\right] \cdot R_{D C}=\left(1+d_{(h)}\right) \cdot R_{D C}
$$

де $y_{s(h)}$ - коефіцієнт збільшення опору жили кабелю, зумовленого поверхневим ефектом, для гармоніки струму $h ; y_{p(h)}$ - коефіцієнт збільшення опору жили кабелю, спричинений ефектом зближення; $y_{a(h)}$ - коефіцієнт збільшення опору, зумовленого впливом оболонки кабелю: $R_{D C}-$ активний опір провідника постійному струму за робочої температури.

Згідно зі стандартом [5] ці коефіцієнти визначають за наведеними нижче формулами. Коефіцієнт збільшення опору жили кабелю, зумовленого поверхневим ефектом:

$$
y_{s(h)}=\frac{x_{s(h)}^{4}}{192+0,8 \cdot x_{s(h)}^{4}} .
$$

Коефіцієнт збільшення опору жили кабелю, спричиненого ефектом зближення:

$$
y_{p(h)}=\frac{x_{p(h)}^{4}}{192+0,8 \cdot x_{p(h)}^{4}}\left(\frac{d_{c}}{D}\right)^{2}\left(0,312\left(\frac{d_{c}}{D}\right)^{2}+\frac{1,18}{\frac{x_{p(h)}^{4}}{192+0,8 \cdot x_{p(h)}^{4}}+0,27}\right) .
$$

Коефіцієнт збільшення опору, зумовленого впливом оболонки кабелю:

$$
y_{a(h)}=0,5 \cdot\left[y_{S(h)}+y_{p(h)}\right] .
$$

$\mathrm{y}$ цих формулах використано такі позначення:

$$
\begin{aligned}
& x_{s(h)}^{2}=\frac{8 \pi h f}{R_{D C}} \cdot 10^{-7} k_{s}, \\
& x_{p(h)}^{2}=\frac{8 \pi h f}{R_{D C}} \cdot 10^{-7} k_{p},
\end{aligned}
$$

де $f$ - промислова частота струму, Гц; $d_{c}$ - діаметр жили провідника, мм; $D$ - відстань між центрами жил, мм; $k_{S}$ і $k_{P}$ - коефіцієнти, що залежать від конструкції кабелю і наведені у табл. 2.

Коефіцієнти $\boldsymbol{k}_{S}$ i $\boldsymbol{k}_{P}$ для різних конструкцій кабелів

Таблиия 2

\begin{tabular}{|c|l|c|c|}
\hline \multicolumn{2}{|c|}{ Тип жили кабелю } & $k_{S}$ & $k_{P}$ \\
\hline \multirow{2}{*}{ Суцільна } & емальована & 1 & 1 \\
\cline { 2 - 4 } & гола & 1 & 1 \\
\hline \multirow{2}{*}{ Багатопровідна } & емальована & 0,35 & 0,15 \\
\cline { 2 - 4 } & гола & 0,40 & 0,30 \\
\hline
\end{tabular}

Враховуючи ці співвідношення, втрати активної потужності в кабелі з несинусоїдним струмом для симетричного навантаження жил можемо визначити за таким виразом:

$$
\Delta P=\Delta P_{1}+\Delta P_{L h}+\Delta P_{N h}=3 I_{(1)}^{2} R_{(1)}+3 \sum_{h=2}^{n} I_{(h)}^{2} R_{(h)}+\sum_{h=3}^{n}\left(3 I_{h}\right)^{2} R_{N(h)},
$$

де $\Delta P_{1}, \Delta P_{L h}, \Delta P_{N h}$ - втрати від струму першої гармоніки, втрати від струмів вищих гармонік у фазних $(L)$ і нейтральній $(N)$ жилах, відповідно; $R_{(1)}, R_{(h)}$ - активний опір фазної жили кабелю для першої та вищих гармонік, $R_{N(h)}$ - активний опір нейтральної жили кабелю.

Відсоток збільшення втрат потужності, спричиненого протіканням гармонік струму, відносно втрат у трифазній лінії під час синусоїдного режиму визначається залежністю:

$$
K_{\Delta P}=\frac{\Delta P}{\Delta P_{1}} \cdot 100 \% .
$$


Важливою характеристикою під час вибору кабелю для нелінійних навантажень $є$ коефіцієнт допустимого навантаження кабелю в цих умовах. Очевидно, що корисне навантаження кабелю пов'язане з основною гармонікою струму навантаження. Тому коефіцієнт корисного навантаження кабелю в умовах спотвореного струму буде меншим, ніж в умовах синусоїдного струму. Оскільки наявність гармонік спричинятиме додаткове нагрівання кабелю, то “корисний” (синусоїдний) струм необхідно знижувати для утримування допустимого нагрівання кабелю. Згідно 3 [10] коефіцієнт допустимого навантаження кабелю визначають за виразом:

$$
N d=\frac{1}{\sqrt{1+\frac{\Delta P_{L h}+\Delta P_{N h}}{\Delta P_{1}}}} .
$$

Формула (6) використовується за умови, що кабель живить симетричне стаціонарне нелінійне навантаження. Як вказано вище, в низьковольтних промислових електричних мережах навантаження у різних фазах $є$ часто змінним і несиметричним. В цих умовах у фазних струмах і струмі нейтрального проводу виникатиме повний спектр гармонік. Крім того особливістю таких мереж $\epsilon$ те, що значення гармонік струму понад 25 не перевищують $0,5 \%$. Враховуючи такий характер навантажень можна запропонувати спрощений метод розрахунку втрат у кабелі, придатний для їх практичного оцінювання.

Коефіцієнти збільшення опору жили кабелю у виразі (1) є нелінійними функціями частоти, які обчислюють за формулами (2)-(5). Причому нелінійність суттєво проявляється в області гармонік, вищих від 25-ї. Це дає підставу застосувати для апроксимації цих коефіцієнтів лінійну залежність, що значно спростить процедуру розрахунку. Такий підхід дасть змогу розрахувати частотну залежність опору кабелю, використовуючи таку формулу:

$$
R_{(h)}=\left(1+d_{(h)}\right) \cdot R_{D C} \approx\left(1+k_{s p} \cdot h\right) \cdot R_{D C},
$$

де $k_{s p}$ - частотний коефіцієнт для жил вибраного типу кабелю.

Несиметрія струму спричиняє додаткові втрати у нейтральному проводі кабелю, які за змінного навантаження можна наближено врахувати коефіцієнтом несиметрії струму за нульовою послідовністю. Тоді загальні втрати у кабелі можна розрахувати за виразом:

$$
\begin{aligned}
& \Delta P=\Delta P_{1}+\Delta P_{L h}+\Delta P_{3 N h}+\Delta P_{0 N h}= \\
& =3 I_{(1)}^{2} R_{(1)}+3 \sum_{h=2}^{25} I_{(h)}^{2} R_{(h)}+\sum_{h=3}^{21}\left(3 I_{h}\right)^{2} R_{N(h)}+\sum_{\substack{h=1, h \neq 3 n}}^{25}\left(3 K_{I 0} I_{h}\right)^{2} R_{N(h)} .
\end{aligned}
$$

\section{Приклад розрахунку втрат потужності у кабелях зі змінним навантаженням}

На рис. 1 показано мережу живлення електрофільтрів теплоелектроцентралі (ТЕЦ) промислового підприємства. Від спільного трансформатора власних потреб на стороні низької напруги, крім електрофільтрів, живлення отримують також інші навантаження системи власних потреб ТЕЦ.

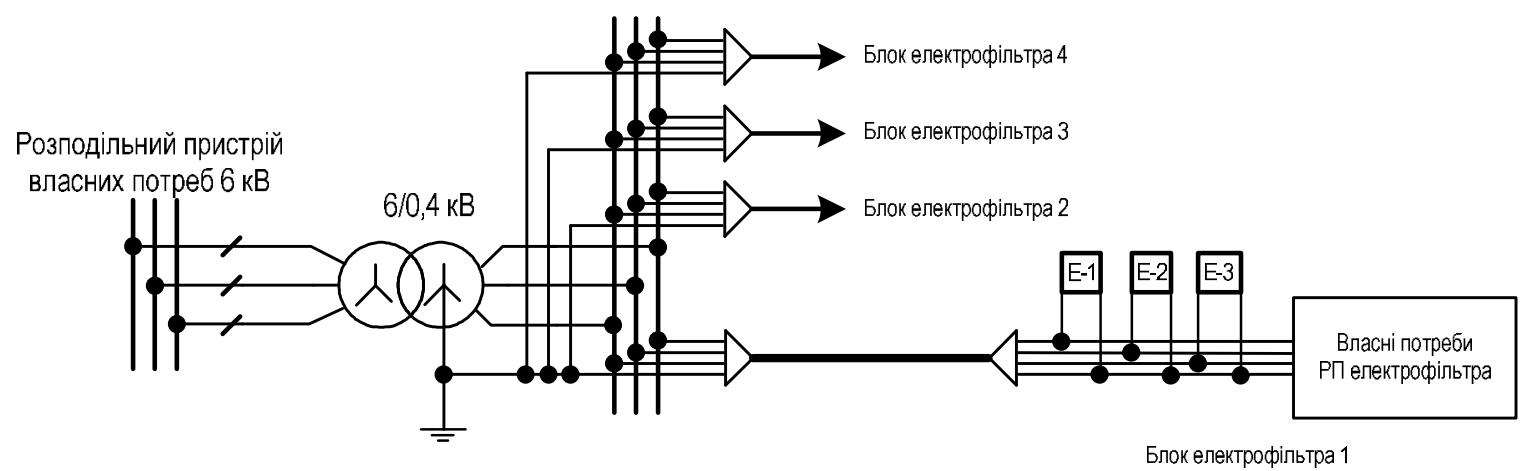

Рис. 1. Принцииова схема живлення електрофільтрів

У табл. 3 наведено дані кабелю XLPE-0,6/1 кB з алюмінієвими провідниками, який використано у системі електропостачання фільтрів. 
Каталожні дані кабелю

\begin{tabular}{|c|c|c|c|c|c|c|c|}
\hline $\begin{array}{c}\text { Кількість } \\
\text { жил та } \\
\text { переріз, } \\
n \times \text { мм }^{2}\end{array}$ & $\begin{array}{c}\text { Товщина } \\
\text { ізоляції } \\
\text { жили, } \\
\text { мм }\end{array}$ & $\begin{array}{c}\text { Товщина } \\
\text { зовнішньої } \\
\text { оболонки, } \\
\text { мм }\end{array}$ & $\begin{array}{c}\text { Діаметр } \\
\text { жили, } \\
\text { мм }\end{array}$ & $\begin{array}{c}\text { Віддаль } \\
\text { між центра- } \\
\text { ми жил, } \\
\text { мм }\end{array}$ & $\begin{array}{c}\text { Активний } \\
\text { опір жили } \\
\text { за } 20{ }^{\circ} \mathrm{C}, \\
\text { Ом/км }\end{array}$ & $\begin{array}{c}\text { Номінальний } \\
\text { струм на } \\
\text { повітрі, } \\
\text { А }\end{array}$ & $\begin{array}{c}\text { Довжина } \\
\text { кабелю, } \\
\text { м }\end{array}$ \\
\hline $4 \times 185$ & 2,0 & 2,7 & 16 & 40 & 0,164 & 350 & 300 \\
\hline
\end{tabular}

У мережі низької напруги 0,4 кВ під час робочих режимів здійснено вимірювання гармонік у струмах живлення електрофільтрів. Отримані результати наведено на рис. 2.

Рис. 2. Максимальні значення гармонік струму навантаження

Як видно, у струмі навантаження електрофільтра наявний практично повний спектр гармонік. Значення гармонік понад 25 не перевищують 0,5..0,7 \%. Коефіцієнт спотворення струму навантаження $K_{\mathrm{HcI}}=40 \%$, активна потужність навантаження системи живлення еелектрофільтрів $P_{H}=820$ кВт, реактивна потужність $-Q_{H}=390$ квар, середнє значення коефіцієнта нульової послідовності струму основної гармоніки $K_{I 0}=15 \%$.

Втрати потужності в кабельній лінії за умови синусоїдного режиму. Згідно з каталожними даними (табл. 3) активний опір кабельної лінії для основної гармоніки струму можна обчислити за виразом:

$$
R_{(1)}=R_{0} \cdot l_{\mathrm{K}}=0,164 \cdot 0,3=0,0492 \text { Ом. }
$$

Максимальне значення струму навантаження трансформатора:

$$
I_{\mathrm{H}}=\frac{S_{\mathrm{H}}}{\sqrt{3} \cdot U_{\mathrm{HH}}}=\frac{\sqrt{P_{\mathrm{H}}^{2}+Q_{\mathrm{H}}^{2}}}{\sqrt{3} \cdot U_{\mathrm{HH}}}=\frac{\sqrt{820^{2}+390^{2}}}{\sqrt{3} \cdot 0,4}=1310,61 \mathrm{~A} .
$$

Припускаючи, що кожна кабельна лінія завантажується такою самою потужністю, значення струму однієї кабельної лінії визначимо за виразом:

$$
I_{(1)}=\frac{I_{\mathrm{H}}}{4}=\frac{1310,61}{4}=327,65 \mathrm{~A} .
$$

Втрати потужності в одній кабельній лінії системи живлення за умови синусоїдного режиму:

$$
\Delta P_{1}=3 \cdot I_{(1)}^{2} \cdot R_{(1)}=3 \cdot 327,65^{2} \cdot 0,0492=15846 \mathrm{BT} .
$$

Втрати потужності в кабельній лінії під час несинусоїдного режиму. Порівняємо результати розрахунку для двох типів кабелів 3 різною конструкцією жил (із суцільними жилами і $з$ багатопровідними жилами), загальні параметри яких наведено в табл. 3.

Згідно $з$ формулами (2) і (3) розраховано коефіцієнти збільшення активного опору жил кабелю для вищих гармонік струму. Для обох типів кабелів на рис. 3, a наведено частотні залежності коефіцієнта збільшення активного опору жили кабелю $d_{(h)}$ за рахунок поверхневого 
ефекту та ефекту зближення жил, а на рис. $3, \sigma$ - частотні залежності питомого активного опору жили кабелю (суцільні лінії).
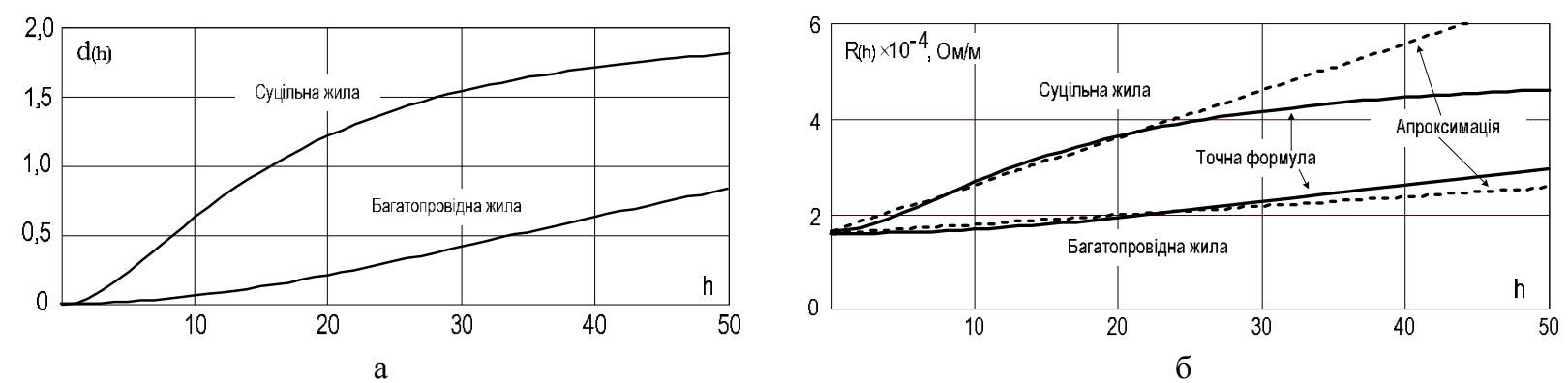

Рис. 3. Частотні залежності коефіцієнта збільшення активного опору жили кабелю (а) та питомого активного опору його жили (б)

Як видно з рис. 4, $a$, в межах 1-25 гармонік в обох випадках функція $d_{(h)}$ виявляє незначну нелінійність. Апроксимуючи у цих межах дійсну функцію $d_{(h)}$ прямою 3 використанням методу найменших квадратів, отримали частотні коефіцієнти для кабелів із суцільними $\left(k_{s p 1}=0,06\right) \mathrm{i}$ багатопровідними $\left(k_{s p 2}=0,012\right)$ жилами. Використовуючи значення цих коефіцієнтів, можемо розрахувати частотні залежності активного опору жил кабелю за спрощеною формулою (9). На рис. 3, б показано апроксимовані частотні залежності питомого активного опору жили кабелю (штрихові лінії).

Втрати активної потужності у фазних і нейтральній жилах кабелю на частотах гармонік розраховано за формулою (10) з використанням точної формули (1) для визначення частотної залежності активного опору жили. Результати розрахунків наведено на рис. 4.

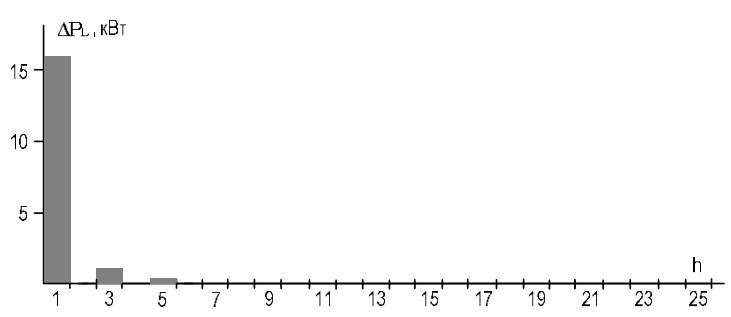

a

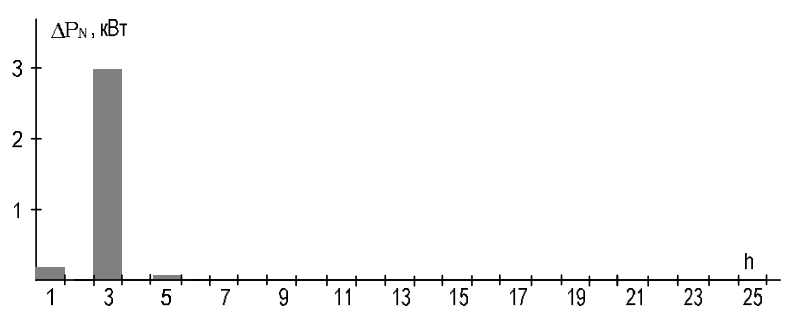

6

Рис. 4. Втрати активної потужності у фазних жилах (а) і у нейтральній жилі кабелю (б)

У табл. 4 наведено порівняння результатів розрахунку втрат у кабелях двох типів, виконаних точним і запропонованим наближеним методом. Можемо відзначити, що запропонований спрощений метод забезпечує високу точність оцінки втрат потужності у кабелях обох типів в умовах несинусоїдних струмів.

Таблиия 4

\section{Втрати потужності у порівнюваних кабелях}

\begin{tabular}{|c|c|c|c|c|c|c|c|}
\hline \multirow{2}{*}{$\begin{array}{l}\text { Тип жили } \\
\text { кабелю }\end{array}$} & \multicolumn{2}{|c|}{$\begin{array}{l}\text { Втрати потужності } \\
\text { у фазних жилах, Вт }\end{array}$} & \multicolumn{2}{|c|}{$\begin{array}{c}\text { Втрати потужності } \\
\text { у нейтральній жилі, Вт }\end{array}$} & \multicolumn{2}{|c|}{$\begin{array}{c}\text { Втрати потужності } \\
\text { у кабелі, Вт }\end{array}$} & \multirow{2}{*}{$\begin{array}{c}\text { Похибка } \\
\text { розрахунку, } \\
\%\end{array}$} \\
\hline & $\begin{array}{l}\text { точний } \\
\text { метод }\end{array}$ & $\begin{array}{c}\text { наближений } \\
\text { метод }\end{array}$ & $\begin{array}{c}\text { точний } \\
\text { метод }\end{array}$ & $\begin{array}{c}\text { наближений } \\
\text { метод }\end{array}$ & $\begin{array}{l}\text { точний } \\
\text { метод }\end{array}$ & $\begin{array}{c}\text { наближений } \\
\text { метод }\end{array}$ & \\
\hline Суцільна & 17400 & 17500 & 3162 & 3382 & 20562 & 20882 & 1,6 \\
\hline Багатопровідна & 17270 & 17310 & 3013 & 3078 & 20283 & 20388 & 0,5 \\
\hline
\end{tabular}




\section{Ю. О. Варецький}

Сумарні додаткові втрати потужності $\Delta P_{L h}$ від протікання струмів гармонік $h=2,3,4 \ldots \mathrm{y}$ фазних жилах становлять:

- для кабелю із суцільними жилами - 1554 Вт;

- д для кабелю із багатопровідними жилами - 1424 Вт ,

а сумарні втрати потужності $\Delta P_{N h}$ від протікання струмів гармонік $h=1,2,3,4 \ldots$ у нульових жилах дорівнюють:

- для кабелю з суцільними жилами - 3162 Вт;

- для кабелю з багатопровідними жилами - 3013 Вт.

Коефіцієнт зростання сумарних втрат активної потужності за наявності гармонік дорівнюватиме:

- для кабелю із суцільними жилами

$$
\mathrm{K}_{\Delta P}=\frac{\Delta P}{\Delta P_{1}} * 100=\frac{20562}{15846} 100=130 \%,
$$

- для кабелю із багатопровідними жилами

$$
\mathrm{K}_{\Delta P}=\frac{\Delta P}{\Delta P_{1}} * 100=\frac{20283}{15846} 100=128 \% .
$$

Коефіцієнт допустимого навантаження за наявності гармонік:

- для кабелю із суцільними жилами

$$
N d=\frac{1}{\sqrt{1+\frac{1554+3162}{15846}}}=0,878,
$$

- для кабелю з багатопровідними жилами

$$
N d=\frac{1}{\sqrt{1+\frac{1424+3013}{15846}}}=0,884 .
$$

Це означає, що в умовах мережі живлення електрофільтрів дійсне навантаження кабелю не повинно перевищувати 87,8 \% від його розрахункового значення, визначеного за каталогом для синусоїдного режиму для кабелю з суцільними жилами, і 88,4 \% - для кабелю з багатопровідними жилами.

\section{Висновки}

У роботі розглянуто проблему збільшення втрат активної потужності в кабельних лініях, які живлять споживачів з нелінійними навантаженнями. Показано, що спотворення струму навантаження кабелю призводить до збільшення втрат активної потужності в ньому за рахунок збільшення активного опору жили кабелю на частотах вищих гармонік струму. Це є наслідком поверхневого ефекту та ефекту зближення провідників, у яких протікають спотворені струми.

Здійснено аналіз особливостей нелінійних навантажень промислових мереж низької напруги i запропоновано спрощений метод оцінювання втрат потужності в чотирижильних кабелях для живлення цих навантажень. Показано, що кожен тип кабелю можна характеризувати певним частотним коефіцієнтом для обчислення частотної залежності активного опору. На прикладі мережі живлення промислових електрофільтрів теплової електроцентралі проаналізовано вплив спотворення струму на рівень втрат у кабельних лініях мережі, а також здійснено порівняння нормативного і наближеного методів розрахунку втрат активної потужності. Результати розрахунків підтверджують високу точність наближеного методу розрахунку втрат.

Наведений приклад показує, що під час вибору кабелів, які призначені для живлення нелінійних навантажень, повинен враховуватися вплив спотворення струму цих навантажень на 
Метод оцінки втрат потужності у кабелях низької напруги промислових електричних мереж

підвищення робочої температури через істотне збільшення втрат активної потужності. Це дасть змогу уникнути можливого пошкодження кабелів чи прискореного старіння їх ізоляції під час експлуатації.

\section{Список літератури}

1. O'Connell K., Barrett M., Blackledge J. \& Sung A. Cable Heating Effects due to Harmonic Distortion in Electrical Installations, Proceedings of The World Congress on Engineering, 2012, pp. 934-938. DOI:10.21427/D79COS.

2. Patil K. and Gandhare W. Effects of harmonics in distribution systems on temperature rise and life of XLPE power cables, Power and Energy Systems (ICPS), 2011 International Conference, 2011, pp. 1-6. DOI:10.1109/ICPES.2011.6156680.

3. Tofoli F., Sanhueza S. And de Oliveira A. On the study of losses in cables and transformers in nonsinusoidal conditions. IEEE Trans. on Power Delivery, vol. 21, 2006, pp. 971-978. DOI:10.1109/TPWRD.2006.870986.

4. Ducluzaux A., Cahier technique no. 83 - Extra losses caused in high current conductors by skin and proximity effects, Schneider Electric, Grenoble 2002, p. 7.

5. IEC Standard 60287-1-1 - Electric Cables - Calculation of the Current Rating, edition 1.2, 2001-11.

6. Desmet J., Vanalme G., Belmans R. and Van Dommelen D.. Simulation of Losses in LV Cables Due to Nonlinear Loads, Proceedings of IEEE Power Electronics Specialists Conference,(PESC 2008), 15-19 June 2008, pp. 785-790. DOI:10.1109/PESC.2008.4592025.

7. Demoulias C. N., Labridis D. P., Dokopoulos P. S. and Gouramanis K. Ampacity of Low-Voltage Power Cables Under Nonsinusoidal Currents, IEEE Trans. on Power Delivery, 22, 2007, pp. 584-594. DOI:10.1109/TPWRD.2006.881445.

8. Topolski Ł., Warecki J., Hanzelka Z. Methods for determining power losses in cable lines with non-linear load. Przegląd Elektrotechniczny, 2018, nr 9, pp. 85-90. DOI: 10.15199/48.2018.09.21.

9. Milardovich N., Prevosto L. and Lara M. A. Calculation of harmonic losses and ampacity in low-voltage power cables when used for feeding large LED lighting loads Advanced electromagnetics, Vol. 3, no. 1, 2014, pp. 5056. DOI:10.7716/aem.v3i1.258.

10. Topolski Ł., Warecki J., Hanzelka Z. Calculating power losses in LV cables loaded with nonsinusoidal currents. Proc. of 2018 Int. Conf. “Computational Problems of Electrical Engineering” CPEE 2018, Banská Štiavnica, September 2018, pp. 9-12. DOI: 10.1109/CPEE.2018.8506716.

\section{References}

1. O’Connell K., Barrett M., Blackledge J. \& Sung A. Cable Heating Effects due to Harmonic Distortion in Electrical Installations, Proceedings of The World Congress on Engineering, 2012, pp. 934-938. DOI:10.21427/D79COS.

2. Patil K. and Gandhare W. Effects of harmonics in distribution systems on temperature rise and life of XLPE power cables, Power and Energy Systems (ICPS), 2011 International Conference, 2011, pp. 1-6. DOI:10.1109/ICPES.2011.6156680.

3. Tofoli F., Sanhueza S. And de Oliveira A. On the study of losses in cables and transformers in nonsinusoidal conditions. IEEE Trans. on Power Delivery, vol. 21, 2006, pp. 971-978. DOI:10.1109/TPWRD.2006.870986.

4. Ducluzaux A., Cahier technique no.83 - Extra losses caused in high current conductors by skin and proximity effects, Schneider Electric, Grenoble 2002, p. 7.

5. IEC Standard 60287-1-1 - Electric Cables - Calculation of the Current Rating, edition 1.2, 2001-11.

6. Desmet J., Vanalme G., Belmans R. and Van Dommelen D.. Simulation of Losses in LV Cables Due to Nonlinear Loads, Proceedings of IEEE Power Electronics Specialists Conference,(PESC 2008), 15-19 June 2008, pp. 785-790. DOI:10.1109/PESC.2008.4592025.

7. Demoulias C. N., Labridis D. P., Dokopoulos P. S. and Gouramanis K. Ampacity of Low-Voltage Power Cables Under Nonsinusoidal Currents, IEEE Trans. on Power Delivery, 22, 2007, pp. 584-594. DOI:10.1109/TPWRD.2006.881445.

8. Topolski Ł., Warecki J., Hanzelka Z. Methods for determining power losses in cable lines with non-linear load. Przeglad Elektrotechniczny, 2018, nr 9, pp. 85-90. DOI: 10.15199/48.2018.09.21. 
9. Milardovich N., Prevosto L. and Lara M. A. Calculation of harmonic losses and ampacity in low-voltage power cables when used for feeding large LED lighting loads Advanced electromagnetics, Vol. 3, no. 1, 2014, pp. 5056. DOI:10.7716/aem.v3i1.258.

10. Topolski Ł., Warecki J., Hanzelka Z. Calculating power losses in LV cables loaded with nonsinusoidal currents. Proc. of 2018 Int. Conf. “Computational Problems of Electrical Engineering” CPEE 2018, Banská Stiavnica, September 2018, pp. 9-12. DOI: 10.1109/CPEE.2018.8506716.

\author{
Y. Varetsky \\ Lviv Polytechnic National University, \\ Department of Electrical Power Engineering and Control Systems, \\ e-mail:j.varetsky@gmail.com
}

\title{
A METHOD OF POWER LOSS ASSESSMENT IN LOW VOLTAGE CABLES FOR INDUSTRIAL ELECTRICAL GRIDS
}

(C) Varetsky Y., 2021

Current harmonics in industrial cable lines are accompanied by harmful phenomena that cause additional active power losses in cable cores. The phenomena are an increasing the insulation temperature and reduction cable lifetime. Failures are often noted in the cable electrical grids due to improper accounting for the impact of harmonics in the cable sizing. Therefore, the correct consideration of the active power loss in cables carrying distorted currents allows for the correct sizing its types and avoid potential problems in the power grid operation. Through considering the concern on estimating additional power losses caused by cable current harmonics the generally accepted method for the loss estimation is analyzed in the paper. The distortion of the load current causes increasing the active power loss in the cable due to cable core resistance gain through increasing the current harmonic frequency. This is due to skin and proximity effects in cable cores with distorted currents.

In low-voltage electrical grids, as a rule, four-core XLPE cables are used and the grid loads are variable. Consequently, the magnitude of the currents and their distortion in individual phases change over time, causing a time-varying asymmetry. This operating condition causes harmonic currents in the neutral conductor of the cable, not only multiples of three, but also the entire spectrum of harmonics existing in the phase currents. The paper presents a practical method of cable ampacity assessment for a low-voltage grid supplying a variable nonlinear load.

The results of the industrial grid load analysis show that under nonsinusoidal conditions each type of cable can be characterized by a certain frequency coefficient for calculating the linear frequency dependence of the cable core resistance. Using the example of the power supply of CHPP electrostatic precipitators, the impact of the current distortions on power losses in cable lines was analyzed, and a comparison was made between the normative and proposed methods for calculating power losses. The results of the analysis confirm the high accuracy of the proposed method for calculating losses. This example shows that under sizing cables supplying nonlinear loads, the impact of the current harmonics of these loads on the increase in cable operating temperature due to a significant increase in active power losses must be taken into account. The correct cable sizing for non-sinusoidal conditions will avoid possible damage to cables or increased aging of their insulation during operation.

Key words: low voltage cable; active power loss; industrial electrical grid; current harmonics; nonlinear load. 